\title{
糖尿病性腎症透析の合併症に関する臨床的検討
}

\author{
柴田昌雄岸常規 \\ 名古屋大学分院内科
}

(昭和 55 年 9 月 4 日受付)

Key words Hemodialysis, Diabetes, Complication, Retinopathy, Prognosis.

〈要旨〉

過去 10 年間, 当科および関連施設で導入された糖尿病透析例について, retrospectiveに調査を行ない, その死因, 合併症について検討を加えた。

患者総数は 62 名で, 男 42 名，女 20 名であった。このうち 27 名の死亡例が認められ，その内訳は男 21 名，女 6 名 であった。

死因としては全身衰弱 7 例, 消化管出血 4 例, 脳血管障害 4 例, 自殺, 心不全各 3 例, 心筋梗塞, 高 $\mathrm{K}$ 血症各 2 例, 感染症 1 例が代表的なものである.

今回の調査では透析導入早期に脳血管障害の発生頻度が高く, 経過とともに消化管出血, 全身衰弱が増加していた。 従って，透析早期の血圧，水分管理と長期透析例での栄養管理が重要と思われた.

合併症として糖尿病性網膜症を中心に調査した。対象患者の視力状態は 19 名が両側失明, 12 名が一側失明であっ た。また透析導入後, 明らかに網膜症が進行した例が 8 名あった。一方, 導入時, すでに 16 名が両側あるいは一側の 失明状態にあった。二の結果, 血液透析が網膜症を進行させるという証拠は見い出せなかった。導入時点での失明例 が多いことから, 導入以前の網膜症の管理も重要であると思われた。これらの患者の社会復帰状態はほぼ満足できる ものであった.

網膜症以外の合併症では, 不安定型高血圧, 糖尿病性胃腸症, 末梢神経炎, 虚血性心疾患, 足壊死などがみられた。 このうち, 社会復帰不能な者は, 末梢神経炎 1 名, 足壊死, 下肢切断の 2 名の計 3 名のみであった。他の例はみな軽 症であった。ただ不安定型高血圧は脳血管障害, 眼底出血の誘引を伴い, 注意を要する。

透析中の合併症では急激な低血圧を呈する例が，全体の $30 \%$ \%らんた。この低血圧に対する対策として，重曹透 析, high $\mathrm{Na}$ 透析, cell washout dialysis 等が行なわれて効果を上げていた。

\section{Clinical study on the complications of dialyzed diabetics}

\author{
Masao Shibata, Tsuneki Kishi \\ Department of Internal Medicine Nagoya University, Branch Hospital
}

Over the past 10 years, we have retrospectively investigated on dialytic therapy of 62 cases of diabetics at our department and our associated hospital. We studied the complications and the cause of death of 62 subjects. Of 62 patients (male 42, female 20), 27 patients (male 21, female 6) were died. The cause of death in 27 cases included 7 general weakness, 4 gastrointestional bleeding, 4 cerebrovascular hemorrhage or thrombosis, 3 suicide, 3 congestive heart failure, 2 myocardial infarction, 2 hyperkalemia, 1 infection and 1 hepatoma.

The cerebrovascular accident often occurred at the early stage of hemodialysis and gastro-intestinal bleeding and general weakness occurred after that.

With regard to diabetic retinopathy, nineteen of 62 patients were bilateral blind and 12 patients were unilateral blind. In 8 patients, visual complications developed after hemodialysis, but 16 patients had been already blind when hemodialysis was introduced.

We didn't find the evidence that the retinopathy was accelerated by dialysis. We suggest that the treatment of 
retinopathy is very important at nondialyzed stage.

With regard to the other complications of dialyzed diabetics, we could find unstable hypertension, diabetic gastroenteropathy, periferal neuropathy, ischemic heart disease and gangrene. All the patients had some ability to rehabilitate except 3 patients (1 periferal neuropathy, 2 leg amputation).

We should be careful of the unstable hypertension because it often induce the cerebralvascular accident and retinal bleeding. Nineteen patients (30\% in all subjects) showed sympton of severe hypotension during dialysis. For the treatment of hypotension, bicarbonate dialysis and high $\mathrm{Na}$ dialysis were effectively practiced.

\section{緒言}

わが国の透析療法は過去 10 年来めざましい進歩をと げ，次第にその適応症の範囲を広げてきた。糖尿病性腎 症（以下腎症と略す）も現在では慢性透析の適応となり 全透析患者に占好腎症透析患者の比率も約 $3.7 \%$ を占 めるに至っている ${ }^{1}$.しかしながら腎症透析例は合併症の 頻度が高く，死亡率も高く，かつ社会復帰困難な例が多 い. 私どもは今回, 過去 10 年にわたる当内科㧍よび関連 施設に打ける腎症透析例について, retrospective に調査 検討を加え，その生存率，死因，合併症などについてい ささかの知見を得たので報告する。

\section{対象ならびに方法}

対象患者は当科㧍よび関連施設で透析導入した腎症の 患者 62 名, 男 42 名, 女 20 名である。こ机ら対象患者の 平均年令は 50 才で, 最少は 26 才, 最高は 78 才であった。 このうち, インスリン使用例は 35 名であり, 若年発症糖 尿病と考えられるものは10名であった。

透析期間については平均は 28.8 か月であり, 透析方法 は全例，週 3 回，1 回当たり 5 時間の血液透析を実施し た。使用へパリン量, ダイアライザーには各症例とも大 差はなく，使用透析液のブドウ糖濃度は 150～200 mg／ $\mathrm{d} l$ の範囲にあった。

\section{結果}

\section{1) 死亡例の検討}

対象患者中, 27 名の死亡例が認められた。内訳は男 21 名, 女6 名であった(表 1)。これらの死亡例の死因の内 訳は表 2 に示す如くである，表にみられるように，死因 で最も多かったのは全身衰弱㧍よび原因不明で7例にみ られた。この原因不明とは複数の疾病が併発し, 死因を 特定しえないものを指している. 以下, 消化管出血が 4 例, 脳血管障害が 4 例, 自殺が 3 例, 心不全㧍よび心停 止が 3 例, 心筋梗塞が 2 例, 高 $\mathrm{K}$ 血症が 2 例, 感染症が 1 例であった。

次に死亡例を透析期間，導入時の年令別に検討した結 果を図 1，2 亿示す。

図 1 にみられるように, 導入後 1 年末満の死亡数 9 名, 1 年以上・ 2 年末満の死亡数 10 名であり, 2 年末満の死 亡数が 19 名と過半数を占めた。他方, 長期生存例もかな

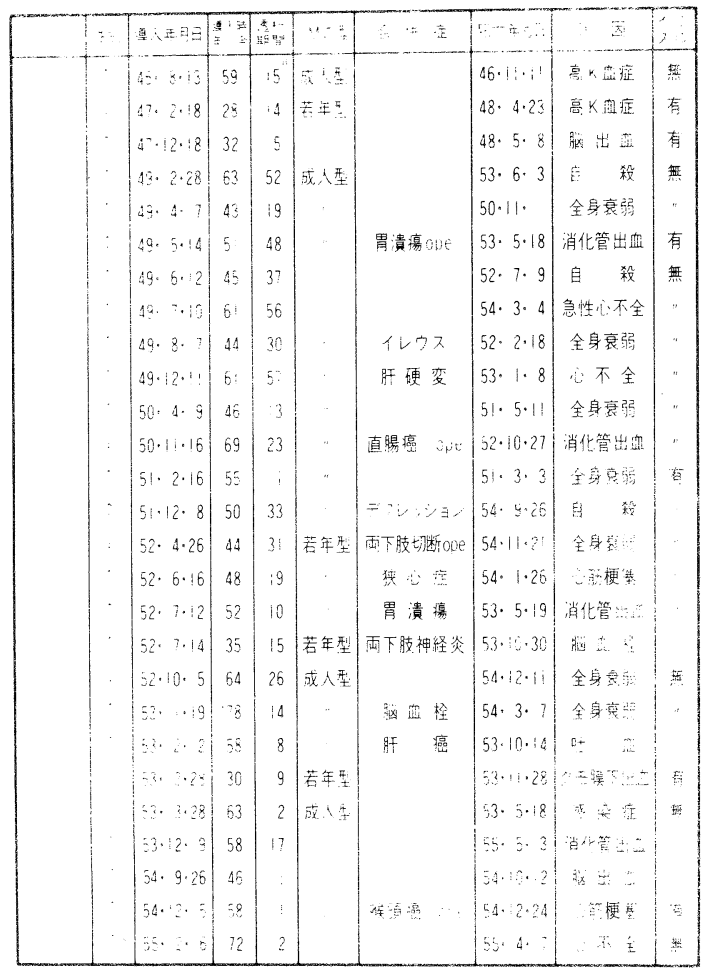

表１ 糖尿病透析患者死亡例（27例）

1. 心血管系

a. 脑血管障害

$$
\left(\begin{array}{ll}
\text { 脳出血 } & 2 \text { 例 } \\
\text { 脳血栓 } & 1 \text { 例 } \\
\text { 毛膜下出血 } & 1 \text { 例 }
\end{array}\right.
$$

b. 心不全及U゙心停止 3 例

c. 心筋硬塞 2 例

2. 感染症 1 例

3. 消化器系

$\begin{array}{ll}\text { (消化管出血 } & 4 \text { 例 } \\ \text { 肝 癌 } & 1 \text { 例 } \\ \text { 殺 } & 3 \text { 例 } \\ \text { 身衰翑及び原因不明 } & 7 \text { 例 } \\ \mathrm{K} \text { 血症 } & 2 \text { 例 }\end{array}$

表2 死因の内訳 


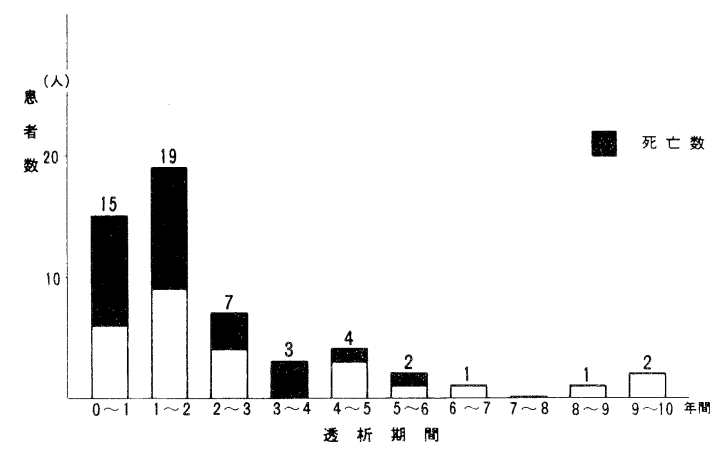

図 । 透析期間よりみた死亡患者数

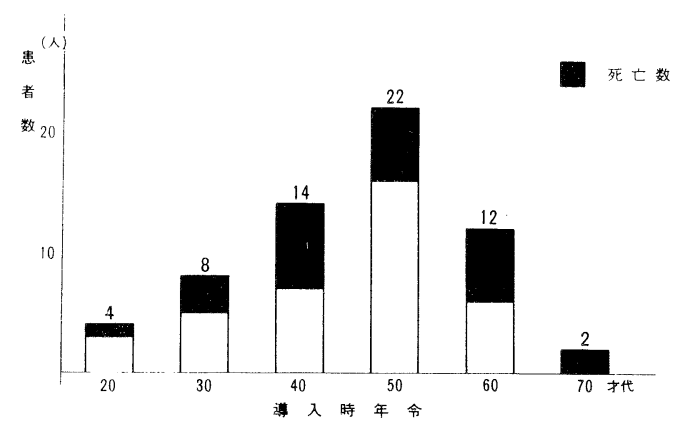

図 2 導入時年歯々死亡者数

りみられ, 最長透析歴は 9 年 9 か月であった。

网 2 でみられるように，導入時年令 60 才以上では 18 例中 8 例が死亡して抒り，高年令の導入例では死亡率が 高いことがうかがわれる。

更に, 死亡例の死因に関連する因子を検索するために， インスリンの有無, 透析期間, 性別, 年令の各因子の分 析を試みた(表 3 ).

表 3 に示す如く, 脳血管障害は導入 1 年末満で, 年令 50 才未満の男性でインスリン使用例に多い傾向がみら れた。また，消化管出血，全身衰弱はインスリン使用の 有無に関係なく, 導入後 1 年以上で, 50 才以上の高令者 に多い傾向がみられた。

2) 網膜症の検討

腎症の透析例では, 他の原発性腎疾患の透析例に比較 して，原疾患による合併症の併発が多い。特に合併症の うち最も重要な糖尿病性網膜症（以下網膜症と略す）に ついて検討を行なった。

表 4 は対象患者の現時点（1980 年 5 月現在）ならびに 死亡時点に扔ける視力の状態を示したものである. 対象 62 名のうち, 19 名が両側失明の状態にあり, 12 名が一側 失明の状態であった。すなわち, 全体の約 $30 \%$ な゙完全失 明の状態であり，また全体の50\%が一側失明以上の状態

\begin{tabular}{|c|c|c|c|c|c|c|c|}
\hline & 联血管㜔害 & 而血管 & 采 & 感染症 & 消化管出皿 & 全身衰弱 \\
\hline \multirow{2}{*}{$\frac{1}{3}$} & 有 & 3 & 0 & 2 & 0 & 2 & 2 \\
\hline & 無 & 1 & 3 & 0 & 1 & 2 & 5 \\
\hline \multirow{2}{*}{$\begin{array}{l}\text { 逶析 } \\
\text { 期間 }\end{array}$} & 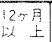 & 1 & 2 & 1 & 1 & 3 & 6 \\
\hline & $\begin{array}{l}2 \% \text { 年 } \\
\text { 未满 }\end{array}$ & 3 & 1 & 1 & 0 & 1 & 1 \\
\hline \multirow{2}{*}{$\begin{array}{l}\text { 性 } \\
\text { 别 }\end{array}$} & 男 & 3 & 3 & 2 & 0 & 3 & 5 \\
\hline & 女 & 1 & 0 & 0 & 1 & 1 & 2 \\
\hline \multirow{2}{*}{$\begin{array}{l}\text { 年 } \\
\text { 命 }\end{array}$} & 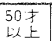 & 0 & 3 & 1 & 1 & 4 & 3 \\
\hline & $\begin{array}{l}50 \text { 㙐 } \\
\text { 末 }\end{array}$ & 4 & 0 & 1 & 0 & 0 & 4 \\
\hline
\end{tabular}

表 3 死因に関連市る諸因子

\begin{tabular}{|c|c|c|c|c|c|c|}
\hline \multirow[t]{5}{*}{ 1) } & 視力の程度 & & & & & \\
\hline & 患者総数 & 62例 & （男 & 42 例, & 女 & 20例) \\
\hline & 両側失明 & 19例 & （男 & 13例, & 女 & 6例） \\
\hline & 一側失明 & 12例 & （男 & 8例, & 女 & 4 例) \\
\hline & 視力低下 & 21 例 & （男 & 13例， & 女 & 8例） \\
\hline \multirow[t]{3}{*}{ 2) } & 合併炡 & & & & & \\
\hline & 白内障合併 & 25 例 & （男 & 16例, & 女 & 9例) \\
\hline & 緑内障合併 & 4 例 & （男 & 4 例, & 女 & 0例） \\
\hline
\end{tabular}

表 4 糖尿病透析患者の視力状態

にあった。

この事実により, 網膜症は, 極めて高頻度でしかも重 大な合併症であることがより明らかになった。そこで， この網膜症の進行に血液透析がいかなる影響を与えてい るかを検討した。

現時点ならびに死亡の時点において両側あるいは一側 の失明例のうち, 導入時の視力状態の明らかなもの 24 例 について, 導入時の視力状態と現時点ならびに死亡時点 の視力状態を比較, 検討した。透析導入後, 網膜症の進 行により，失明に至った症例は 8 例であった。かかる例 在進行群とし，表 5 に示した。他方，導入時点で，すで に16例に抒いては失明状態にあったことは重要である。 この事実は血液透析の直接的影響がなくても, 腎不全に 至万間に糖尿病患者では網膜症の程度もかなり重篤とな っていることを示している。

次に, 表 5 に示した進行群も含めて失明例を, 性別, 透析期間，導入時年令，インスリン使用の有無および血 圧，体重の管理の各因子について分析した。その結果, 血圧不安定群が 8 例中 4 例にみられたが，この血圧の不 安定は網膜症の進行に何らかの関与の可能性が示唆され た。

綱膜症による視力障害は, 透析患者の社会復帰を阻害 し, 重大な問題である。私どもの今回の検討では, 現時 点での生存例 35 名のうち, 20 例に一側失明以上の視力 障害がみられた。このうち, 完全失明 13 例であり, 透析 


\begin{tabular}{|c|c|c|c|c|c|c|c|c|}
\hline 比石 & 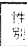 & 潮人年月日 & $\begin{array}{ll}\text { 零 } \\
\end{array}$ & 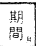 & 都 & 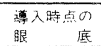 & 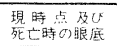 & ₹ \\
\hline & & $49 \cdot 5 \cdot 14$ & 51 & 48 & 有 & Scott IIt & $\begin{array}{l}S \operatorname{Scott} v \\
\text { 舟失明 }\end{array}$ & 血压不安定 \\
\hline & $=$ & $49 \cdot 6 \cdot 12$ & 45 & 37 & 無 & Scott N & $\begin{array}{l}S \operatorname{scot} v \\
\text { 耐失 明 }^{2}\end{array}$ & 血厓不安定 \\
\hline & $\because$ & $50 \cdot 8 \cdot 6$ & 54 & 57 & 有 & Wagner III & 両失明 & \\
\hline & : & $53 \cdot 1 \cdot 20$ & 62 & 28 & 無 & Wagner IV & $\begin{array}{l}\text { 左硝子体出榓ope } \\
\text { 左 }\end{array}$ & 血圧不安定 \\
\hline & $\because$ & $53 \cdot 5 \cdot 13$ & 50 & 24 & 有 & Wagner IV & $\begin{array}{l}\text { Wagner rf V } \\
\text { 左失 明 }\end{array}$ & 局所ヘハリン化 \\
\hline & : & $53 \cdot 9 \cdot 8$ & 26 & 20 & 有 & Wagner III & $\begin{array}{l}\text { Wagner } v \\
\text { 耐失明 }\end{array}$ & 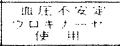 \\
\hline & . & $53 \cdot 11 \cdot 24$ & 61 & 18 & 有 & Wagner II & 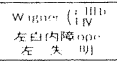 & \\
\hline & 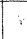 & $54 \cdot 6 \cdot 28$ & 54 & 11 & 有 & Scott III- V V & $\begin{array}{l}S \operatorname{Scottr} V \\
\text { 右失明 }\end{array}$ & \\
\hline
\end{tabular}

表 5 網膜症進行例

1）心血管柔

$\begin{array}{lr}\text { 心筋硬塞 } & 2 \text { 例 } \\ \text { 狭心症 } & 5 \text { 例 } \\ \text { 末梢血管障害 } & \\ \quad \text { 足壞死 } & 6 \text { 例 } \\ \quad \text { 下肢切断 } & 2 \text { 例 } \\ \text { 脳動脈硬化, 脳美縮 } & 2 \text { 例 } \\ \text { 高血圧 (不安定型) } & 11 \text { 例 }\end{array}$

2) 神経系

末悄神経炎 15 例

(内，歩行障害 1 侧)

起立性低血压 12例

胃腸症

16 例

3）感染症

肺結核例

4) 管

$\begin{array}{ll}\text { 管 折 } & 4 \text { 例 } \\ \text { 翼所性石疢化 } & 2 \text { 例 }\end{array}$

（2例と寻歩行障害）

表 6 糖尿病透析患者の合併症

(対象患者総数 62例)

形態では家庭透析が 1 例, 入院透析が 2 例, 外来通院透 析が 10 例であった。完全失明例はまず就業不能であり， 狭義の社会復帰は困難であるが，家庭に帰るという広義 の社会復帰注果しえていると思われた。一方，一側失明 例は 7 例であり，このうち 2 例は他の合併症にて入院中 であったが, 他の 5 名は, 外来通院透析を行なっており, 社会復帰も良好であった。

3)他の合併症の頻度

表 6 は腎症透析例の網膜症以外の合併症の頻度を示し たものである。このうち重篤でかつ社会復帰阻害要因と なるものは足壊死の進行例で下肢切断に至ったもの, ま た糖尿病性あるいは尿毒症性の神経炎の進行によって歩 行障害に陷ったものである.しかし，その例数は少なく， 3例にみられたに過ぎなかった。

心筋梗塞の 2 例は透析導入後に軽症の発作がみられた
ものであるが，その後の経過は良好であった。狭心症は 5例にみられ，透析時に狭心発作を伴うものが多かった。

末梢神経炎, 糖尿病性胃腸症は頻度は高いが軽症のも のが多かった。脳動脈硬化症, 脳萎縮は 2 例にみられた が，所謂，透析脳症の症例はみられなかった。不安定な 高血圧, 起立性低血圧の併発頻度も高く，これらは脳血 管障害，硝子体出血，転倒による骨折等のより重篤な合 併症を引き抢こす誘引になると考えられる。

表 7 は腎症の透析患者の blood access と合併症を示 したものである. 対象患者中外シャント 20 名, 内シャン ト 32 名, 人工血管等の移植血管の 9 名であり, 作製不能 は 1 例にすぎなかった。 blood accessの合併症としては 閉塞, 狭窄, 偽動脈瘤形成に上る血流途絶, 凝血例が多 く, 5 回以上の手術をしたものが 10 例にのぼった。その 他, 感染症は 9 例, スチール症候群は 2 例にみられた。

腎症透析では，透析中の合併症が多く，透析実施困難 な症例もみられる。今回の検討では, 透析中に頻回の低 血圧を呈する例が 18 名にみられ, 全体の約 $30 \%$ に達し ていた。透析困難な一部の症例には, 重曹液による透析, 高 $\mathrm{Na}$ 液透析, 所謂 cell washout dialysis, $\mathrm{Na}$ gradient

\begin{tabular}{|c|c|}
\hline 1) 外シャント & 20 例 \\
\hline 上肢 & 11例 \\
\hline 下肢 & 8 例 \\
\hline 鼠径部 & 1例 \\
\hline 内シャント & 32 例 \\
\hline 血管移植 & 9例 \\
\hline 作成不能 & 1例 \\
\hline 併 症 & \\
\hline 感染症 & 9例 \\
\hline 凝血（5回以上の Ope.) & 10 例 \\
\hline スチール症候群 & \\
\hline
\end{tabular}

表 7 糖尿病透析患者のblood access と合併症 (患者総数 62例)

1) 合 俳 贸:

不均衡症㬋期

18例

(此叮の低血压)

狭心㜚

4 例

高血糖

2例

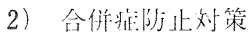

Bicarbonate dialysis 3 例

Cell washout or
$\mathrm{Na}$ gradient dialysis 4 例

利圧剂持続点滴

4 例

表 8 糖尿病透析患者の透析中の合併症

(刘毠 患者総数 62例) 
dialysisが行なわれていた。

\section{考案}

今回の私どもの検討は retrospectiveなものであり， その調查が長期，多施設にわたっており，一部不明の点 もあった。しかし対象患者 62 名を followすることがで きた。この対象患者数汁諸外国の報告数 ${ }^{2) ~ 18)}$ と変わらず, 充分な検討に耐えうるものと考えられる。

そこで，今回の私どもの結果と主にアメリカ合衆国 (USA) に扔ける報告 ${ }^{2) 18)}$ と比較検討し，わが国の腎症 透析の特徵について考案を加えた。

まず腎症透析例の生存率であるが，USA においては， 他の原発性腎疾患の透析例に比して低く，かつ透析年数 を追うごとに生存率は急速に低下すると報告599 されてい る。この事実が糖尿病による腎不全を腎移植の適用とす る 1 つの根拠ともされている.

私どもの結果は, 1 年生存率は $84.4 \%, 2$ 年生存率は $64.9 \%$ で，5 年生存率でみても $34.7 \%$ と極めて良好な 成績であった。

USA で最高の生存率を示した Ma ら ${ }^{4)}$ 報告では 1 年生存率は $86 \%$ であり,私どもの成績はこれとほぼ等し い.またRao ら ${ }^{3} の$ Minnesota Group の報告でも 4 年生 存率は 20 数\%の低さである.これらの報告と比較してみ ると,わが国の腎症の透析は，その長期生存に大きく寄 与していると考光られる。最長透析歴 9 年 9 か月の腎症 患者が存在するという事実がこれを例証している.

このUSA と日本の差は死因にも現われている.USA の死因をみると, 心筋梗塞の頻度が極めて高く, Rao ら ${ }^{31}$ の報告では初期の死因の $62.5 \%$, 後期の死因の $23 \%$ を 占めている。これに対し，私どもの結果では，心筋梗塞 による死亡は 2 例であり,心不全を含めても5例であり， $20 \%$ にみたない。この差異はUSAに比較して，わが国 の糖尿病患者の代謝異常の程度, 例えば糖質代謝の程度, また食事内容に扔いても異なるためと考元られる。この 点については今後，一層の検討を要する問題と考える.

わが国の死因で特徵的であるのは，全身衰弱や消化管 出血の死因に占める割合が高いことであろう。これらは 高令者，長期透析例に多く，糖尿病性代謝異常に加えて 栄養摂取量の不足が malnutrition を促進しここのような 死因を増加させている一因と考えられる.

私どもの成績で, 透析導入初期に脳血管障害が多く, 後期では消化管出血, 全身衰弱が多くなるという事実が 示されたが, この点を考慮すると, 導入初期の水分, 高 血圧の管理，後期に扮ける栄養管理が，わが国での腎症 透析の管理のポイントになると思われる。

網膜症は USA の報告9でも，全体の約 $20 \sim 40 \%$ に失 明をもたらすとされており，私どもの結果と大差はなか
つた。ただUSAの報告では, 血液透析が網膜症の進行に 大きく関与していることが示されている。Rubin らは全 体の $32.6 \%$ に網膜症の進行がみられたといっている.し かし，私どもの検討では血液透析導入後に網膜症の進行 を明らかに認めたものは 8 例にすぎなかった。これは全 患者の約 $13 \%$ に過ざず，失明患者の $25 \%$ に当たるもの であった。透析が網膜症の進行に影響するという事実は， 今回の私どもの検討では得られなかった。

透析時に使用するへパリンが網膜症を進行させるとい う説もあるが，关の事実もみられなかった。網膜症の進 行例 8 例中， 4 例に水分管理，高血圧管理の不充分な例 がみられたことは，むしろ，これらの管理の徹底の方が 進行防止に有用なのかも知れない。

網膜症について重要なことは，透析導入時すでに失明 しているものが 16 例の多くにのぼった。これらはす心゙ て，腎不全の保存的療法中に失明状態に楩ったものであ る。このことは，腎不全の保存療法期の網膜症の管理が 重要であることを示唆している. Kjelstrand ら ${ }^{6)}$ は血清 クレアチニンが 7〜 $10 \mathrm{mg} / \mathrm{d} l$ のうちに透析導入を行な う方が網膜症の進行を防止し得るといっている。

網膜症の進行防止という観点より，血液透析の導入時 期を決定することも必要と思われた。

今回の検討では失明率 $57 \%$ にもかかわらず，48.5\% の患者が何らかの形で社会復帰していることが明らかに なった。両側失明患者でも, 就業不能であっても, 家庭 に帰して，外来通院透析の方向にもっていくことが必要 である。一側失明患者は，できる限り就業させることが 必要であろう。

腎症透析例の合併症については, USA で報告 $3(8) 18$ され ている重篤な糖尿病性胃腸症，透析脳症はみられなかっ た。また, 狭心症, 心筋梗塞の数も少なかった。

透析中の合併症では，透析中，頻回に低血圧を呈する 例が多く，各施設ともその対策に苦慮していた。重曹液 透析，高ナトリウム液透析，cell washout dialysis， $\mathrm{Na}$ gradient dialysis 等の透析方法が，これらの症状の発現 の防止に効果があるといわ机て扔り，今後の検討を要す る問題と思われた。

\section{結論}

1。腎症透析患者の死因上りみて,透析導入早期には 脳血管障害が多く，経過とともに消化管出血，全身衰弱 が増加した。従って初期の血圧・水分管理と長期透析例 での栄養管理が重要と思われた。

2. 網膜症の進行に血液透析が関与しているか否かは 明らかにしえなかった。一方，透析導入時点での失明例 の多いことから，導入以前の網膜症の管理が重要と思わ れた。また腎症における透析導入時期を網膜症の進行と 
の関連で考慮する必要があると考える。

3. 網膜症以外の合併症で, 社会復帰上, 問題となる ものは，末梢神経炎による歩行障害，末梢循環障害によ る重症の足壊死であるが, 今回の調査では, その例数は 少なかった。

本論文の要旨は第 25 回人工透析研究会シンポジウム “糖尿病性腎症、にて報告した。

終わりに本研究の調查に御協力いただいた下記の諸施 設に深謝致します。

上飯田第 1 病院，新生会第 1 病院，中京病院，知立ク リニック，白楊会病院，増子病院（50 音順）

\section{文献}

1）小高通夫：わが国の透析療法の現況，人工透析研究 会会誌，12（2）：541-547，1979.

2) J. E. Rubin, E. A. Friedman : Dialysis and transplantation of dibetics in the United States, Nephron $18: 309-315,1977$.

3) K. V. Rao, D. Sutherland, C. M. Kjellstrand, J. S. Najarian, F. L. Shapiro: Comparative results between dialysis and transplantation in diabetic patients, Trans. Am. Soc. Artif. Internal Oragans, 23 : 427-432,1977.

4) K. W. Ma, D. S. Malsler, D. C. Brown: Hemodialysis in diabetic patients with chronic renal failure, Ann. Intern. Med. 83 : 215-217,1975.

5) F. L. Shapiro, A. Leonard, C. M. County : Motality, morbidity and rehabilitation results in regularly dialyzed patients with diabetes mellitus, Kidney Int., 6(Supp1 1) : S-8-14, 1974.

6) C. M. Kjellstrand: Dialysis in Diabetics, Strategy in renal failure, ed by E. A. Friedman 345-362, John Wiley \& Sons, N. Y., 1978.

7) C. R. Blagg: Visual and vascular problem in dialyzed diabetic patients, Kidney Int., 6(supp1 1) : S-27-31,1974.

8) G. F. Cahill, A. Leonard, M. Ellenberg, B. H. Scribner, C. M. Kjellstrand, R. E. Wilson: Discussion: Neurological complication, Kidney Int., 6(suppl 1) : S95-99, 1974.
9) A. Leonard, C. County, L. Raij, T. Rattazzi, R. Wathen, F. Shapiro: The national history regulaly dialyzed diabetics, Trans. Am, Soc. Artif Internal Oragans, $14: 282-286,1973$.

10) B. I. Chazan, S. B. Rees, M: C. Balodimos, D. Younger, B. D. Ferguson: Dialysis diabetics. A review of 44 patients, J. Am.Med. Ass., 209 : 2026 2030,1969

11) W. Druckker, W. A. G. Haaggma-Schouten, C. H. R. Alberts, B. Baarda : Report of regular dialysis in Europe, Proc. Eur. Dial. Transpl. Ass., 7 : 3-7, 1970 .

12) J. Knepshield: Diabetic nephropathy. results of treatment with dialysis and transplantation, Abstr. Int. Congr. Nephrology, 5:25, 1972.

13) M. Ghavamian, C. F. Gutch, K. F. Kopp, W. J. Kolff: The sad truth about hemodialysis forendstage diabetic nephropathy, J. Am. Med. Ass., $222: 1386,1972$.

14) N. White, S. A. Snowden, V. Parsons, J. Sheldou, M. Bewick : The management of terminal renal failure in diabetic patients by regular dialysis therapy, Nephron, 11:261-275, 1973.

15) E. Schupak, M. S. Neff, R. Slifkin, A. Baez : Hemodialysis and diabetic nephropathy, J. Am. Med. Ass., $223:$ 1157, 1973.

16) C. Huang, F. Greco, P. Ivanovich, F. A. Krumlovsky, J. Roguska, N. M. Simon, J. Hano: Maintenance dialysis for diabetic nephropathy with uremia, J. Chron. Dis., 28 : 365-374, 1975.

17) R. F. Slifkin, N. S. Neff A. Baez, S. Gupta, N. Mattoo, M. Haimov: Maintenance dialysis in diabetic patients, in Dial. Transpl. Neph. Proc. 13th Congr. EDTA. Hamburg, 377-384, Pitman Med, Kent, 1976.

18) C. M. County, D. Kjellsen, F. L. Shapiro: A reassessment of the prognosis of diabetic patients treated by chronic hemodialysis, Trans. Am. Soc. Artif. Internal Organs, 22 : 404-410, 1976. 